\title{
Learning Material Changes as the Impact \\ of the 2013 Curriculum Policy for the Primary School/Madrasah Ibtidaiyah in Indonesia
}

\author{
Andi Prastowo \\ Universitas Islam Negeri Sunan Kalijaga Yogyakarta, Indonesia \\ andi.prastowo@uin-suka.ac.id \\ Fitriyaningsih \\ Universitas Islam Negeri Sunan Kalijaga Yogyakarta, Indonesia \\ 19204082001@student.uin-suka.ac.id
}

\begin{abstract}
Every curriculum change in Indonesia impacts other components in the national education system, including the learning material. However, main material changes have not been discussed completely. This article presents the analysis result about the impact of 2013 curriculum for Primary School (PS) and Madrasah Ibtidaiyah (MI) in Indonesia on the subject materials. This study used a literature review which examined various applicable 2013 policy documents and textbooks as a representation of the core materials. The findings of this study indicate that the change from the 2006 curriculum to the 2013 curriculum in PS/MI level has an impact on changes in teaching material. The structure and method changes are more structured, hierarchical and not overlap among levels, due to core competencies. The presentation is thematic and from concrete to abstract. Material content also changes. Teaching materials in the 2013 curriculum in PS/MI level are contextual, integrative and focused on character and soft skills. Teaching materials in the 2013 Curriculum also covers critical and creative thinking, communicative, and collaborative learning.
\end{abstract}

Keywords: Curriculum policy; 2013 curriculum; Elementary School; Madrasah Ibtidaiyah; core materials 


\begin{abstract}
Abstrak
Setiap perubahan kurikulum di Indonesia berdampak kepada perubahan komponen lainnya di dalam sistem pendidikan nasional, salah satunya yaitu aspek materi pokok. Namun, perubahan pada materi pokok itu menyangkut sisi apa saja masih belum dibahas secara tuntas. Artikel ini menyajikan hasil kajian mengenai dampak perubahan kebijakan Kurikulum 2013 untuk sekolah dasar dan madrasah ibtidaiyah di Indonesia terhadap materi pokok. Kajian ini menggunakan metode penelitian literature review, yakni dengan mengkaji berbagai dokumen kebijakan 2013 yang berlaku dan buku-buku teks pelajaran sebagai representasi dari materi pokok. Temuan dari penelitian ini menunjukkan bahwa perubahan dari kurikulum 2006 ke kurikulum 2013 pada jenjang primary school / madrasah ibtidaiyah telah berdampak pada perubahan materi ajar. Struktur dan cara penyajian materi berubah, lebih terstruktur, hierarkis, dan tidak tumpang tindih antar tingkat dan antar jenjang, karena adanya kompetensi inti. Penyajiannya secara tematik dan dari konkret ke abstrak. Konten materi juga berubah. Materi ajar dalam Kurikulum 2013 di jenjang PS/ MI menyajikan materi-materi yang kontekstual, integratif, bermuatan karakter dan softskill. Materi ajar dalam Kurikulum 2013 juga melatih keterampilan berpikir kritis, berpikir kreatif, komunikatif dan kolaboratif..
\end{abstract}

Kata kunci: Kebijakan kurikulum; kurikulum 2013; Sekolah Dasar; Madrasah Ibtidaiyah; materi pokok

\title{
A. Introduction
}

Educational policy has an important role in determining the direction of education in a country (Fattah, 2014, p. 136). Policy is the direction for the implementation of programs and activities in solving a problem (Anderson, 2003, p. 2). Education in Indonesia currently has various kinds of problems, especially regarding low quality. Program for International Student Assessment (PISA) in 2018 proved such a state. The PISA 2018 report revealed that the ability of Indonesian students in the fields of Science, Mathematics, and literacy was lower than the achievements of students in Singapore, Malaysia, Vietnam, Thailand, and Brunei Darussalam (OECD, 2018, p. 15,18). The curriculum is one of the main highlights as the cause of the low education quality in Indonesia. The basic argument is that the curriculum is a key factor in quality reform in the education unit (Irwanto \& Suryana, 2016, p. 148) 
Curriculum change is a necessity in the dynamics of education to preserve the education quality. The government took the policy to change the 2006 Curriculum with the 2013 Curriculum (for primary education and secondary education) is one of the strategic efforts in responding he challenges and needs. The following are several challenges and needs of a very dynamic changing era including moral degradation of students, the low achievements of Indonesian students in international surveys, the influence of rapid advances in information technology and the internet on people's lifestyles. Through the eleventh curriculum change since Indonesia's independence, one of the expectations is that the quality of education in schools/madrasas will be better and be able to compete with other countries in the world (Hidayat, 2015, p. 1).

The education system has several components and the curriculum is one of its components. The curriculum becomes an essential element in the component input (Shaleh, 2004, p. 249). Changes in the curriculum will have an impact on changes in other components in the system. Article 1 of the Law of the Republic of Indonesia Number 20/2003 states that "The National Education System is a whole component of education that is interrelated in an integrated manner to achieve the objectives of national education" (President of the Republic of Indonesia, 2003). The curriculum changes so the subject matter component also changes automatically. Pastowo added that the preparation of subject matter for teaching materials must follow the applicable curriculum (Prastowo, 2014, p. 138). Thus, curriculum changes have the great potential to bring impact, namely changes in the subject matter of learning.

Many experts have researched curriculum changes. The focus of the study so far concerns the following topics: the impact of curriculum changes on teaching (Guthrie, 1986), the factors that determine curriculum reform (Handal \& Herrington, 2003), the impact of curriculum changes on students' skills, attitudes and values (Greybeck et al., 2004), the impact of curriculum changes on the learning approach of students (Walker et al., 2010), the impact of curriculum changes on classroom activities ( $\mathrm{Li} \& \mathrm{Ni}, 2011$ ), the impact of curriculum changes on learning strategies (Moyer et al., 2011; Veken et al., 2009). The review of previous studies shows that research concerning the impact of curriculum changes on the subject matter is probably still rare. Therefore, the research topic becomes essential and urgent to complete the study of the impact of curriculum changes. Based on the various arguments and explanations above, the discussion of the impact of changes in the 2013 curriculum policy on the subject matter is an important and urgent issue.

This article is the result of research with a qualitative approach. The main research data are in the form of writings. Such as government policies in the field of PS and MI 
curriculum, official guidelines and guidelines on curriculum implementation, as well as official textbooks that present the subject matter in primary schools and madrasah ibtidaiyah. The use of qualitative approaches becomes very relevant for exploring and analyzing such types of data. That choice refers to Afrizal's opinion, which states that the process of analyzing data in the form of writings uses qualitative research (Afrizal, 2017, p. 18). The research method uses literature review. Indarti and Paramita explained that "systematic literature studies use a more detailed and clearly defined approach to study in a specific specific area with the aim of answering more specific research questions" (Indarti \& Paramita, 2017, p. 260). The author analyzes the data by identifying themes that emerge from the research data. These themes are the result of classification of research data codes. The process of preparing the theme takes focus to address the research problems. The main point of this research problem is the change in subject matter as a result of changes in the 2013 curriculum for elementary schools and madrasah ibtidaiyah.

\section{B. Discussion}

The change in the subject matter in primary schools and madrasah ibtidaiyah in Indonesia is the impact of the implementation of the 2013 curriculum regulation or called the K-13 regulation. The application of the 2013 Curriculum policy regulation has several differences from the previous curriculum, namely the 2006 Curriculum or known as the Education Unit Level Curriculum or called Kurikulum Tingkat Satuan Pendidikan (KTSP) in Indonesia. The differences in some aspects of the 2013 curriculum have an impact on changes in the subject matter in several aspects. A full explanation of differences in the 2013 Curriculum and KTSP as well as changes in subject matter as a result of the 2013 Curriculum regulations in PS / MI are as follows.

\section{Differences in the 2013 Curriculum and the 2006 Curriculum for PS / MI}

The K-13 policy for PS/ MI, which underwent the last major revision in 2016 has a legal basis namely "Government Regulation No.13 of 2015 Jo. Government Regulation No. 32 of 2013 Jo. Government Regulation No. 19 of 2005 concerning National Education Standards "(President of the Republic of Indonesia, 2005, 2013, 2015). The juridical basis is a reference for changing the 2006 curriculum to K-13. The initiator is the Government, in this case, the Ministry of Education and Culture. Therefore, changing the curriculum requires changes in advance on a higher legal basis, namely the National Education Standards. Slameto revealed that four standards changed as a result of 2013 curriculum policies, namely "Graduates 
Competency Standards, Content Standards, Process Standards, and Assessment Standards" (Slameto, 2015).

Derivative regulations are in the form of special policies that are more operational as guidelines for implementing the 2013 curriculum in the form of Minister of Education and Culture Regulations or called MOEC Regulations. The Regulation of K-13 at the Ministerial level has changed at least twice, some even five times. The beginning of the application of K-13 in Indonesia was July 2013. The reference regulations are nine regulations of Education and Culture Minister (Permendikbud) as follows: (1) MOEC Regulation No. 54 of 2013 concerning "Graduate's Competency Standards" (Minister of Education and Culture, 2013d), (2) MOEC Regulation No. 64 of 2013 concerning "Content Standards" (Minister of Education and Culture, 2013e), (3) MOEC Regulation No. 65 of 2013 concerning "Standards for Primary and Secondary Education Process" (Minister of Education and Culture, 2013g), (4) MOEC Regulation No. 66 of 2013 concerning "Education Assessment Standards" (Minister of Education and Culture, 2013f), (5) MOEC Regulation No. 67 of 2013 concerning "Basic Framework and Curriculum Structure of Primary Schools / Madrasah Ibtidaiyah" (Minister of Education and Culture, 2013c), (6) MOEC Regulation No. 81A of 2013 concerning "Curriculum Implementation (Minister of Education and Culture, 2013b), dan (7) MOEC Regulation No. 71 of 2013 concerning "Textbooks and Primary and Secondary Education Teacher Guidebooks" (Minister of Education and Culture, 2013a).

The government made a second change to the regulations of the 2013 Curriculum in 2014. It means still one year the curriculum policy was changed. This regulation change has two forms, namely adding new rules and replacing old rules with new ones. Several new regulations have emerged to complement the previous MOEC Regulations, namely: (1) MOEC Regulation No. 103 of 2014 concerning "Learning in Primary and Secondary Education" (Minister of Education and Culture, 2014e), (2) MOEC Regulation No. 104 of 2014 concerning "Assessment of Learning Outcomes by Educators in Primary and Secondary Education" (Minister of Education and Culture, 2014h), (3) MOEC Regulation No. 63 of 2014 concerning "Scouting Education as a Compulsory Extracurricular Activity in Primary and Secondary Education" (Minister of Education and Culture, 2014g), (4) MOEC Regulation No. 105 of 2014 concerning "Assistance for the Implementation of the 2013 Curriculum in Primary and Secondary Education" (Minister of Education and Culture, 2014f). Whereas the new regulations to replace the old regulations, namely: (1) MOEC Regulation No. 61 of 2014 concerning "Education Unit Level Curriculum in Primary and Secondary Education" (this regulation is to replace the MOEC Regulation No. 81A of 2013) (Minister of Education and 
Culture, 2014d), (2) MOEC Regulation No. 62 of 2014 concerning "Extracurricular Activities in Primary and Secondary Education" (this regulation is to replace Permendikbud No. 81A of 2013) (Minister of Education and Culture, 2014b), and (3) Permendikbud No. 159 of 2014 concerning "Curriculum Evaluation in Primary and Secondary Education" (this regulation is to replace Permendikbud No. 81A of 2013) (Minister of Education and Culture, 2014a), and (4) MOEC Regulation No. 57 of 2014 concerning "2013 Primary School / Madrasah Ibtidaiyah Curriculum" (Minister of Education and Culture, 2014c).

The Ministry of Religious Affairs (Indonesia) also issued regulations in response to various regulations from the MOEC. This regulation concerns on the K-13 in madrasah. The policy took the form of the Minister of Religious Affairs Decree or called MORA Decree. This MORA Decree refers to the 2013 Curriculum regulations issued by the Ministry of Education and Culture. The following are three new rules regarding 2013 Curriculum in Madrasas, namely: (1) MORA Decree No. 207 of 2014 concerning "Madrasa Curriculum" (Minister of Religious Affairs, 2014b), (2) MORA Decree No. 117 of 2014 concerning "Implementation of the 2013 Curriculum in Madrasas"(Minister of Religious Affairs, 2014a), (3) MORA Decree No. 165 of 2014 concerning "Guidelines for 2013 Madrasa Curriculum Subjects in Islamic Education and Arabic Language"(Minister of Religious Affairs, 2014c).

In 2015, there was a third change to regulation at the level of MOEC Regulations. The changes were indeed not so much. Changes to the 2013 Curriculum reference regulations in 2015 namely from MOEC Regulation Number 104 of 2014 replaced with MOEC Regulation Number 53 of 2015 concerning "Assessment of Learning Outcomes by Educators and Education Units in Primary and Secondary Education" (Minister of Education and Culture, 2015). Thus, MOEC Regulation No. 104 of 2014 no longer applies to the advent of the new regulation.

The fourth amendment to the 2013 Curriculum regulations was implemented massively in 2016. Graduates Competency Standards, Content Standards, Process Standards, Assessment Standards, and Core Competencies and Basic Competencies for 2013 Curriculum have all changed. The previous Ministerial Regulation no longer applies. A new term emerged from the 2013 Curriculum policy, which was published in June 2016, namely the revised 2013 Curriculum. Several regulations at the ministry level as a juridical basis for the implementation of the 2013 Curriculum which are the results of 2016 revisions are: (1) MOEC Regulation No. 20/2016 concerning "Competency Standards for Primary and Secondary Education Graduates"(Minister of Education and Culture, 2016d), (2) MOEC Regulation Number 21 of 2016 concerning "Content Standards for Primary and Secondary Education" (Minister of 
Education and Culture, 2016c), (3) MOEC Regulation number 22/2016 concerning "Primary and Secondary Education Process Standards" (Minister of Education and Culture, 2016f), (4) MOEC Regulation No. 23 of 2016 on "Standards for Primary and Secondary Education Assessment"(Minister of Education and Culture, 2016e), (5) MOEC Regulation Number 24 of 2016 concerning "Core Competencies and Basic Competencies of Learning in the 2013 Curriculum" (Minister of Education and Culture, 2016b). The regulations that have changed and not replaced are MOEC Regulation Number 8 of 2016 on "Books Used by Education Units" (Minister of Education and Culture, 2016a).

The fifth regulatory change occurred in 2018. This year, the government made minor changes to the formulation of Basic Competencies. The results of these changes are in the form of MOEC Regulation Number 37 of 2018 concerning "Amendment to the Minister of Education and Culture Regulation Number 24 of 2016 concerning Core Competencies and Basic Competencies for Curriculum Learning in 2013". This new regulation regulates the need for integration of Informatics content in lessons for PS / MI, while for Junior High Schools or Madrasah Tsanawiyah and Senior High Schools / Madrasah Aliyah adding one subject namely Informatics (Minister of Education and Culture, 2018).

The Ministry of Religious Affairs also made changes to the 2013 curriculum regulations for Islamic Education and Arabic Language in Madrasas in 2019. The newest regulation was the MORA Decree Number 183 of 2019. This decree was concerning "Curriculum of Islamic Education and Arabic Language in Madrasas". This policy also revoked MORA Decree Number 165 of 2014 concerning "2013 Madrasah Curriculum Guidelines for Islamic and Arabic Language Education Subjects" (Minister of Religious Affairs, 2019a). The following policy is MORA Decree Number 184 of 2019 concerning "Guidelines for Implementing Curriculum in Madrasas". This policy also revoked MORA Decree Number 117 of 2014 concerning "Implementation of 2013 Curriculum in Madrasas" (Minister of Religious Affairs, 2019b). The explanation shows that the 2013 curriculum policy has changed at least five times in the Ministry of Education and Culture and twice in the Ministry of Religious Affairs of the Republic of Indonesia. However, the change does not occur in all regulations..

Meanwhile, the difference between the 2013 Curriculum and the 2006 Curriculum or called KTSP is the following. First is the Education Unit Level Curriculum (the 2006 Curriculum) is a curriculum created by the work of the autonomous education unit that is operational and following their respective characteristics. The principles that form the basis of the 2006 Curriculum development are: "(1) centred on the potential, development, needs, and 
interests of students and their environment, (2) diverse and integrated, (3) relevant to the needs of life, (4) learning throughout life, and (5) balanced between national interests and regional interests " (Leo Agung, 2015).

Second, the 2013 Curriculum (K-13) is a competency-based curriculum that has an emphasis on character education. The purpose of implementing the curriculum is that national education in Indonesia can produce superior human resources, able to compete at the global level, and have character (President of the Republic of Indonesia, 2005). In other words, the orientation of the 2013 curriculum is not just to produce a generation that excels in aspects of knowledge and aspects of its skills but also excels in aspects of attitude.

Character education in the 2013 curriculum has a goal that is to encourage the creation of improved quality of human resources oriented to character and noble character as a whole. The 2013 curriculum integrates character education into all subjects. Therefore, value education and character-building use indirect teaching mode.

Meanwhile, internalization of character education is internalized through real practice in the context of everyday life (Mulyasa E, 2013, p. 21.). Character education emphasizes exemplary to students, the creation of a conducive environment, and positive habituation through various learning tasks (Mulyasa E, 2013). Table 1 presents the essence of the differences between the 2006 Curriculum and the 2013 Curriculum.

Table 1. Differences in the 2006 Curriculum and the 2013 Curriculum

\begin{tabular}{|c|c|c|}
\hline \multirow{2}{*}{ ASPECT } & \multicolumn{2}{|c|}{ CURRICULUM } \\
\hline & The 2006 Curriculum & The 2013 Curriculum \\
\hline Learning object & $\begin{array}{l}\text { Use the following concepts: } \\
\text { Graduates Competency } \\
\text { Standards (GCS), Competency } \\
\text { Standards (CS), Basic } \\
\text { Competencies (BC), Indicators } \\
\text { and Objectives in each } \\
\text { subject;GCS for each subject and } \\
\text { class refers to Minister of } \\
\text { National Education (MONE) } \\
\text { Regulation Number } 23 \text { of } 2006 \\
\text { The main foundation as well as } \\
\text { the direction of the development } \\
\text { of subject matter are CS and BC. } \\
\text { Likewise, learning activities, and } \\
\text { formulation of competency } \\
\text { achievement indicators as a } \\
\text { reference for assessment also } \\
\text { refers to CS and BC. } \\
\text { CS and BC are partial because } \\
\text { they cover all domains of } \\
\text { competence. BC is also not } \\
\text { explicitly mapped/grouped in the }\end{array}$ & $\begin{array}{l}\text { - Using concepts, namely: } \\
\text { Graduates Competency } \\
\text { Standards (GCS), Core } \\
\text { Competencies (CC), Basic } \\
\text { Competencies (BC), Indicators } \\
\text { and Learning Objectives } \\
\text { GCS refers to MOEC Regulation } \\
\text { No. } 20 \text { of } 2016 \text {; CC and BC refer } \\
\text { to MOEC Regulation No. } 37 \text { in } \\
\text { 2018 jo.24 in } 2016 . \\
\text { CC at one level / class in one } \\
\text { level is the same, but different } \\
\text { for different levels / classes; CC } \\
\text { is hierarchical until an SKL is } \\
\text { achieved at an educational } \\
\text { level.BC covers all areas of } \\
\text { learning (attitudes, knowledge, } \\
\text { and skills) in all subjects. } \\
\text { Holistic and comprehensive } \\
\text { learning objectives cover all } \\
\text { domains of competence. }\end{array}$ \\
\hline
\end{tabular}




\begin{tabular}{|c|c|c|}
\hline & $\begin{array}{l}\text { realm of learning (attitudes, } \\
\text { knowledge, and skills). Teachers } \\
\text { must identify themselves }\end{array}$ & \\
\hline $\begin{array}{l}\text { Content and Study } \\
\text { Materials }\end{array}$ & $\begin{array}{l}\text { Knowledge, or attitude, or skill. } \\
\text { All three do not have to be all, } \\
\text { either one or several. } \\
\text { Teachers and students have } \\
\text { autonomy in choosing and using } \\
\text { learning textbooks. } \\
\text { There is no need to use certain } \\
\text { textbooks. } \\
\text { The main requirement is that the } \\
\text { book has received validation } \\
\text { from the ministry. }\end{array}$ & $\begin{array}{l}\text { Knowledge, attitude and skills; } \\
\text { Presenting thematic-integrative } \\
\text { material for PS/ MI } \\
\text { Presentation of teaching } \\
\text { materials in the form of student } \\
\text { books and teacher books } \\
\text { Student books and teacher books } \\
\text { become the primary reference } \\
\text { and teaching material; } \\
\text { Lack of flexibility to use study } \\
\text { material outside the textbook. }\end{array}$ \\
\hline Learning Activities & 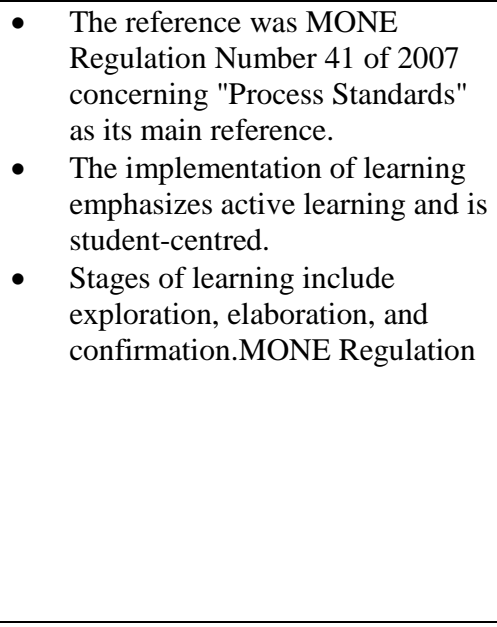 & 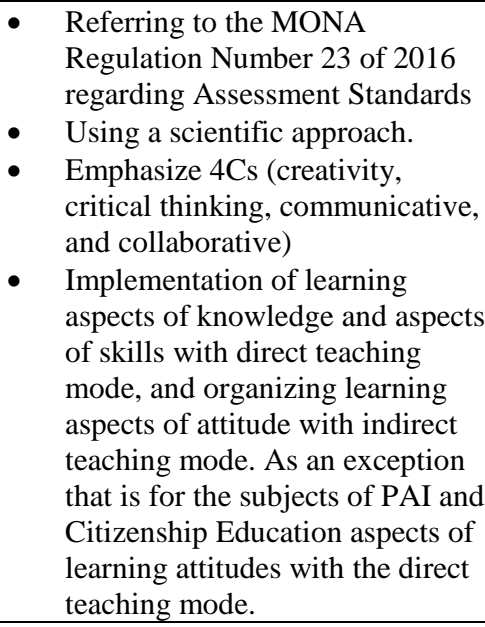 \\
\hline Assessment & $\begin{array}{ll}\text { - } & \text { Refer to MONE Regulation } \\
& \text { No.20 of } 2007 \\
\text { - } & \text { Using class-based assessments } \\
\text { - } & \text { Ratings use numbers as a basis }\end{array}$ & $\begin{array}{l}\text { Refer to MOEC Regulation } \\
\text { Number } 22 \text { of } 2016 \text {; } \\
\text { All subjects use authentic } \\
\text { assessments, which include } \\
\text { evaluating aspects of attitudes, } \\
\text { knowledge and skills in their } \\
\text { entirety } \\
\text { The form of the results of the } \\
\text { assessment report in the form of } \\
\text { numbers, predicates and } \\
\text { descriptions }\end{array}$ \\
\hline $\begin{array}{l}\text { Syllabus and Learning } \\
\text { Plan }\end{array}$ & $\begin{array}{l}\text { Implementing syllabus } \\
\text { developers is an independent } \\
\text { school or a specific group in } \\
\text { coordination with the local } \\
\text { education office; } \\
\text { The developer of the LP is the } \\
\text { teacher, and the reference is } \\
\text { MONE Regulation Number } 23 \text { of } \\
\text { 2006. }\end{array}$ & $\begin{array}{l}\text { Syllabus developers are the } \\
\text { Ministry of Education and } \\
\text { Culture; schools as users; } \\
\text { The teacher develops a LP based } \\
\text { on MOEC Regulation No. } 22 \text { of } \\
2016 \text { and MOEC Regulation No. } \\
24 \text { of } 2016 \text { Jo. } 37 / 2018 \text { as well as } \\
\text { Student Books and Teacher's } \\
\text { Books. }\end{array}$ \\
\hline
\end{tabular}




\section{Changes to Learning Subject Material in the 2013 Curriculum for PS and MI}

The subject matter of learning in all subjects presented at the primary school (PS) and madrasah ibtidaiyah (MI) has changed along with the application of the new curriculum policy, namely the 2013 Curriculum. Changes in the subject matter of learning in the 2013 Curriculum for PS and MI occur in 7 (seven) aspects, namely: (1) presenting thematic subject matter in an integrated manner for all subjects, except for Pancasila and Citizenship Education or PCE, Islamic Religious Education (or called IRE), and Mathematics (specifically for classes IV, V, and VI), (2) the material is arranged contextually and concretely, (3) standard subject matter has been prepared by the government and is ready for use, (4) material is prepared by scientific approach, (5) subject matter for all subjects in the realm of knowledge and skills is taught by direct learning mode (direct instruction), except PCE and PAI subjects are added with attitude material; (6) subject matter is structured to stimulate critical thinking, creative, communicative, and collaborative skills for students, (7) subject matter is integrated with basic literacy material, and (8) subject matter is integrated with character education strengthening programs. A full explanation of the 8 points of change in subject matter is presenting below.

First, the presentation of subject matter uses integrated thematic for all subjects, except subjects: (1) Physical Education, Sports, and Health (specifically grades IV, V, and VI), (2) Mathematics (grades explicitly IV, V, and VI), and (3) Islamic Religious Education (PAI) from class I to class VI. At the beginning of the application of the 2013 curriculum, the presentation of subject matter using integrated thematic was seven subjects, namely (1) Pancasila and Citizenship Education, (2) Indonesian Language, (3) Mathematics, (4) Social Sciences (starting to formulate Basic Competence / Special KD in class IV), (5) Natural Sciences (starting formulated BC in class IV0, (6) Culture and Craft, (7) Physical Education, Sports, and Health Themes used in integrated thematic approaches These consist of classes I and II each with eight themes, class III and IV each with nine themes, class V with five themes, and class VI with six themes. One subject whose learning does not use integrated thematic, but subject-based learning, namely Islamic Religious Education (IRE). The integration (integration) approach used in the 2013 Curriculum includes four approaches: are intradisciplinary approach, an inter-disciplinary approach, short multidisciplinary power, and a trans-disciplinary approach (Minister of Education and Culture, 2013).

After running for about 1 year, MOEC Regulation No. 57 of 2014 replaces MOEC Regulation No. 67 of 2013. Although changing regulations, the substance of the contents relating to the presentation of the subject matter is still the same as the contents of MOEC Regulation No. 67 of 2013. The equation is in the presentation of the subject matter of 
learning in PS/ MI. Presentation of learning subject matter with an integrated thematic approach includes Indonesian Language, Mathematics, Natural Sciences, Social Sciences, Citizenship Education, then Arts, Culture and Crafts, and Physical Education, Sports, and Health. Presentation of the subject matter content uses themes that are contextual with the daily lives of students. As an exception is the subject of Islamic Religious Education. Therefore, the implementation of these subjects is subject based.

Meanwhile, the location of the subject matter changes for SD / MI is in the number of themes used to present the material. Class I and II still contain eight themes each. The names of the themes are still as in MOEC Regulation No. 67 of 2013. The total number of themes in Class III has changed from 9 to 8 themes. Several themes also experienced changes. The number of themes in class IV is still nine themes with the same theme name. The number of class $\mathrm{V}$ themes changed from five themes to nine themes. Class $\mathrm{V}$ has added four new themes. Class VI also changed, from six themes to nine themes. Class VI added three new themes. While the integrated approach (integration) is still as in the previous policy, namely intradisciplinary, inter-disciplinary, multidisciplinary, and trans-disciplinary (Minister of Education and Culture, 2014c).

Subject matter in primary schools/madrasah ibtidaiyah changed again after the establishment of the 2013 curriculum policy, which was revised in 2016. Ministry of Education and Culture Regulation No. 24 of 2016 replaces MoEC Regulation No. 57/2014. Referring to Ministry of Education and Culture Regulation No. 24/2016 states that the presentation of Physical Education, Sports and Health learning materials, and Mathematics learning materials in grades IV, V, and VI uses a subject-based approach (Minister of Education and Culture, $2016 \mathrm{~b})$. In other words, the presentation of the two primary materials does not use a thematic approach - integrated again starting in June 2016 whereas Islamic Religious Education subjects still present learning material as a stand-alone subject.

Furthermore, MOEC Regulation Number 24 of 2016 also does not touch or change the names of themes and the integration approach used. Student thematic books and teacher thematic books after the issuance of the regulation also still present the same themes as the previous regulations, namely MOEC No. 57/2014. Presentation of material content, basic competencies, and themes also still show the application of the four types of integration approach, namely, intra-disciplinary approach, inter-disciplinary approach, multidisciplinary approach, and finally, trans-disciplinary approach. Therefore, based on empirical evidence, the number and name of themes and the integrated approach in presenting the primary material in 
the revised 2013 Curriculum policy have not changed, or are the same as the explanation in MOEC Regulation No. 57/2014.

The conclusion does not have a strong enough regulatory basis because MOEC Regulation No. 24 of 2016 itself did not explain the themes and approaches of integration/integration in thematic learning. Another weakness of this new regulation (MOEC Regulation No. 24 of 2016) is that it does not present a curriculum structure, although article 1 paragraph (2) states "The 2013 curriculum in primary and secondary education as referred to in paragraph (1) consists of: ( a) basic curriculum framework; and (b) curriculum structure "(Minister of Education and Culture, 2016b). However, the regulation does not discuss curriculum structure. This fact also means that in the regulation, there are incomplete parts. Furthermore, in 2018, the government will issue new regulations again as part of the changes to the 2013 curriculum, namely MOEC Regulation No. 37 of 2018 concerning "Amendment to MOEC Regulation No. 24 of 2016" but in no way addresses the issue of the theme or approach of integration (Minister of Education and Culture, 2018). Thus, the existence of the new regulation does not affect the previous policy as stipulated in Permendikbud No. 24/2016..

Second, the subject matter is presented contextually with the flow of material presentation from concrete to abstract. As explained implicitly in the 2013 Curriculum regulations, especially in MOEC Regulation No. 65 of 2013 namely the implementation of learning activities emphasized with a scientific approach, thematic-integrated, and themes, and using research-based learning models (discovery/inquiry) as well as problem-based learning or project-based learning models (Minister of Education and Culture, 2013g). The regulation explicitly emphasizes that learning encourages students to produce contextual work. MOEC Regulation No. 57 of 2014 and MOEC Regulation 22/2016 also explained that the implementation of thematic-integrated learning in PS/MI presents reality in creative teaching and learning activities (Minister of Education and Culture, 2014c, 2016f). The real world context in thematic learning makes the existence of contextual material a necessity.

The names of themes and sub-themes indicate the presence of the subject matter of learning contextually with a thematic-integrated approach and with the flow of presentation from concrete to abstract. The existence of these themes and sub-themes has a function to bind the material content of various subjects. The following are examples of theme names for class I, "Myself, My Interests, My Activities"; for themes in class II for example: "Living in Peace, Playing in my neighbourhood, My Daily Duty"; for themes in class III for example: "Animal and Plant Breeding, Technology Development, Change in Nature"; for the theme in class IV 
for example: "Beautiful Togetherness, Always Save Energy, Care for the Environment"; for themes in class V for example: "Objects in the Surrounding Environment, Events in Life, Healthy is Important"; and for themes in class VI for example: "Save sentient beings, Unity in difference, figure, and inventor" (Minister of Education and Culture, 2014c). Meanwhile, examples of contextual subthemes include subtheme for Myself Theme in Class I PS / MI: "Me and a New Friend, My Body, I Take Care of My Body, and I Am Special"(Hendrifiana et al., 2017, p. xvi). Another example is the list of sub-names for the theme of "Saving Sentient Beings" in Class VI PS / MI consisting of: "My Friends, Animals, Friends, Let's Save Animals and Plants, I Love Reading" (Anggari et al., 2018, p. vi).

Besides, the thematic book for students also presents the flow of material presentation from concrete to abstract. The flow of material presentation from concrete to abstract is a way of presenting material that initially presents actual content or something tangible or something that is familiar to students then only presents abstract information content, in the form of symbols or things that are invisible or human conceptual results. Thematic Book for PS / MI Class I Students The theme "Myself" presents an example in Figure 1.

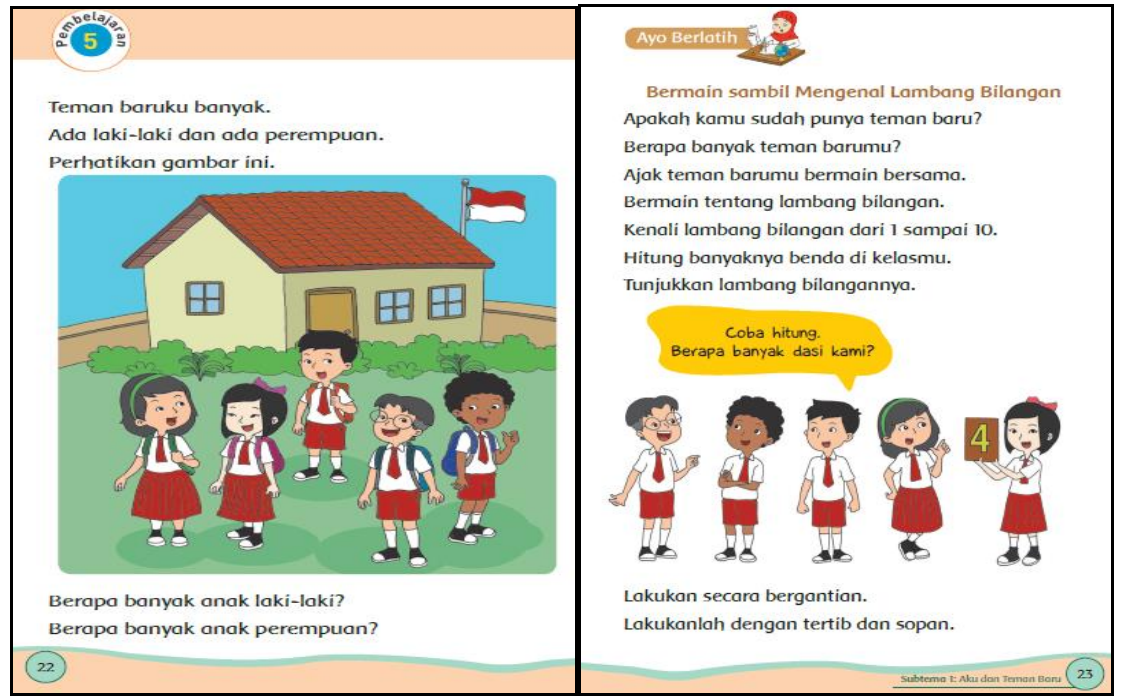

Figure 1. Presentation of Learning Materials from Concrete to Abstract in the Thematic Book of PS / MI Students in Class I on"Mysel"

(Hendrifiana et al., 2017, pp. 22-23)

Figure 1 presents a sequential two-page display (pages 22 and 23) of the Thematic Book for Students with the theme "Myself" The "Me and New Friends" subtheme learning fifth for PS / MI grade 1. Page 22 presents concrete material illustrated in the drawings of boys and girls who still wear primary school uniforms. Then, the bottom part of the picture presents two 
questions namely, (1) "How many boys?", and (2) "How many girls?" Next, page 2 presents the material content about "Playing While Recognizing the Number Symbol". The page presents an exercise in getting to know the 1-10 number symbols with classmates' themes..

Third, the government has prepared teaching materials and the role of the teacher as the user. The 2013 Curriculum Policy already stipulates that the government or private sector has a role as the party who prepares textbooks for the subject matter in primary schools and madrasah ibtidaiyah, not each educational unit or supporting teacher in charge of making them. The Review Team from the Ministry of Education and Culture is the party in charge of determining the feasibility of textbooks published by the Ministry. At the same time, the National Education Standards Agency is the party responsible for determining the feasibility of textbooks published by the private sector. This policy also means that the teacher does not have the task to compile textbooks. MOEC Regulation No. 65 of 2013 concerning "Process Standards" regulates that "Textbooks are used to improve the efficiency and effectiveness of learning in an amount adjusted to the needs of students". The MOEC Regulation No. 71 of 2013 states that the textbooks that are determined to be suitable to be used as PS / MI students' books, including for Class I the title of the book "(1) Myself, (2) My Love, (3) My Activities, (4) My Family "(Minister of Education and Culture, 2013a). MOEC Regulation No. 8 of 2016 confirms the explanation in MOEC Regulation No. 71 of 2013, namely "textbooks are the main source of learning to achieve basic competencies and core competencies and are declared feasible by the Ministry of Education and Culture for use in education units". MOEC Regulation No. 8 of 2016 also explained that, "the publication of textbooks can be done by the Ministry or the private sector by complying with and fulfilling the conditions set in the regulation"(Minister of Education and Culture, 2016a). The existence of this policy also means that the local wisdom of each region lacks accommodation in the textbook. Therefore, making the textbooks through a centralized process, not the autonomy of each teacher or education unit..

Fourth, the preparation of material used a scientific approach. The subject matter in the 2013 Curriculum was revised in 2016. Its preparation refers to the "Basic and Secondary Education Content Standards" contained in MOEC Regulation No. 21 of 2016, MOEC Regulation No. 22 of 2016 concerning "Standard Process for Primary and Secondary Education", MOEC Regulation No. 23 of 2016 concerning "Assessment of Primary and Secondary Education", and MOEC Regulation No. 24 of 2016 concerning "Core Competencies and Basic Competencies of Primary and Secondary Education". Whereas in the 2013 Curriculum the initial stage of its application the preparation of subject matter refers to 
MOEC Regulation No. 64/2013 concerning "Content Standards for Primary and Secondary Education", MOEC Regulation No. 65/2013 concerning "Basic and Secondary Education Process Standards", MOEC Regulation No. 66/2013 concerning "Assessment Standards", and MOEC Regulation No. 67/2013 concerning "Basic Framework and Curriculum Structure of Primary Schools / Madrasah Ibtidaiyah". The presentation of material follows a scientific learning approach. MOEC Regulation No. 22 of 2016 regulates that learning activities in primary and secondary education units are emphasized in order to use a scientific learning approach (Minister of Education and Culture, 2016f). According to the regulation, the process of implementing learning with a scientific approach includes: observing activities, asking questions, trying activities, reasoning activities, presenting activities, and creating activities. The process has an impact on the composition of the presentation of subject matter in PS / MI that follows the flow of the scientific approach.

An overview of the presentation of subject matter that follows the scientific approach can be found in various learning activities on various sub-themes and themes in Thematic Books for Students from Class I to Class IV. As among the learning activities, one sub-theme "Me and My New Friends" in the Thematic Book for Students Theme "Myself" grade I PS / MI. The initial learning activity opens with the material "Let's Observe", then on the next page, two materials "Let's Try" are presented, then the material "Let's Practice" is presented next. After the material "Let's Practice", the material "Let's Sing" is displayed. The next material is "Let's Practice," and the last part is "Activities with Parents" (Hendrifiana et al., 2017).

Another example is the learning material 1 sub-theme "Plant Friends" the theme "Save Sentient Beings" in the Thematic Book for Primary Schools/Madrasah Ibtidaiyah Class VI Students. In learning one sub-theme "Plant is My Friends", the teacher starts the material with the activity "Let's Discuss." In this section, students observe images of the surrounding environment. Students then make questions related to plants as a source of life. The next activity is "Let's Read" an Edo observation report. Students in this section write down the main ideas of each paragraph in the Edo report. The results of the work are then discussed with friends in the group. Presentation of "Let's Observe" material is after the material "Let's Read". The material "Let's discuss" presents about the results of previous observations. The next material is "Let's Practice", "Let's Write", "Let's Contemplate", and finally, "Cooperation with Parents"(Anggari et al., 2018).

The four examples of presentation material in the two Thematic Books for PS / MI in Class I and the two Thematic Books for Class VI show that the presentation of the material uses a scientific approach. The teacher can use the scientific approach to flexibly or not rigidly. 
The Thematic Book for Students presents the main material in the PS / MI in stages from the things that are the result of students' daily observations to the material that is conceptual or procedural. The presentation of subject matter is not instantaneous from abstract concepts to concrete examples. However, the inductive pattern is a choice of thinking lines in the presentation of PS / MI subject matter. The flow of inductive thinking is also one of the characteristics of a scientific approach.

Fifth, subject matter learning for all subjects in the realm of knowledge and skills uses the direct learning mode, except for Civics and IRE subjects. In the 2013 Curriculum regulation, MOEC Regulation No. 81A of 2013 regulates that several types of material are delivered in a direct learning mode, such as knowledge aspects and skills aspects. Meanwhile, the delivery of the material aspects of the attitude, in general, use indirect learning mode, unless the material aspect of attitude on the subjects of Islamic Religious Education and Civic Education (Minister of Education and Culture, 2013b). The government has never made a policy like this in the regulation of the Education Unit Level Curriculum (2006 Curriculum). The 2013 Curriculum Regulation, which underwent revision in 2016, did not explicitly discuss the two learning modes. Nevertheless, the government still continues the direct and indirect learning rules. As Permendikbud No. 24/2016 states that the achievement of social attitudes and spiritual attitudes competencies through "indirect teaching (indirect teaching)" (Minister of Education and Culture, 2016b).. Meanwhile, the achievement of knowledge competencies and skills competencies through direct learning (direct teaching). In the 2013 curriculum, learning orientation directs students towards mastery of knowledge and skills that can develop students' spiritual and social attitudes, while adjusting to the characteristics of student" (Inayati \& Trianingsih, 2019). So, both direct learning and indirect learning, the implementation uses an integrative learning model. Direct learning is related to learning regarding material for the achievement of BC from CC-3 and CC-4. Through this direct learning BC from CC-1 and CC-2 is integrated and entrusted. (Minister of Education and Culture, 2013b).

The thematic book for students in PS / MI also shows that the presentation of the subject matter in the 2013 Curriculum uses a scientific approach. For example, in the Thematic Book for PS / MI Class I Students in the first learning activity, the sub-theme "Me and My New Friends", the theme "Myself". The preparation of learning material starts with the material "Let's Observe", then on the next page displays two materials "Let's Try" and the material "Let's Practice". After the material "Let's Practice", the book presents the material "Let's Sing". The next material is "Let's Practice". Finally, the closing material is "Activities with Parents" (Hendrifiana et al., 2017). One example of the presentation of the subject matter in the 
Thematic Book for Elementary / Primary School Students in Class I shows that the presentation of the material encourages students to construct their own knowledge. The strategy trains students to mobilize all their efforts, including encouraging the active involvement of students to participate in the learning process. Thus, students get active and constructive learning experiences. Learners understand the material gradually until they get an understanding of new abstract concepts. The presentation of learning material is aligned with a scientific approach that uses the foundation of constructivist learning theory.

Sixth, the design of the subject matter stimulates critical thinking skills, creative thinking, communicative skills, and collaborative skills for students. In the 2013 curriculum regulation, which underwent revision in 2016, the subject matter in PS / MI must also integrate the development of soft skills to equip students with $21^{\text {st }}$-century skills. The 21 stcentury skills include critical thinking skills, creative thinking, communication, and collaboration. MOEC Regulation No. 22 of 2016 called it mental skills (soft skills)(Minister of Education and Culture, 2016f). Ariyana, et al, added that the government had implemented a 21 st century education framework into 21 st-century education standards in Indonesia called "Indonesian Partnership for 21 Century Skill Standard (IP-21CSS)"(Ariyana et al., 2018, p. 16). The IP-21CSS includes 4Cs (Creativity Thinking and Innovation, Critical Thinking and Problem Solving, Communication and Collaboration), ICTs (Information, Media, and Technology Skills), Character Building, and Spiritual Values. The implementation of IP21CSS in schools and madrasas is multidisciplinary. In other words, the integration of IP$21 \mathrm{CSS}$ is through all subject matter.

The 2017 revised Thematic Book for Students also shows the integration of 4Cs in the subject matter in PS / MI. Like creative and innovative thinking skills, teachers can grow them through learning 2 sub-themes "Plant Friends" the theme "Save Sentient Beings" PS / MI Class VI in the "Come on Be Creative" activity. This activity trains students to make sculptures from clay or wax night. The book also provides instructions that encourage students' creativity. Which is as follows: "You can try different shapes using clay or wax. Get used to your hands to form the design you expect. Try several shapes using the same ingredients " (Anggari et al., 2018). These instructions stimulate students' imagination and creativity. Likewise, instructions that state "shape the design you hope for" can trigger the creative potential of each student because students are given freedom of expression.

Teachers can also grow critical thinking skills and problem-solving through the thematic subject matter. An example is the Thematic Book for PS / MI Students Class VI learning 1 sub-theme "Plant My Friends" the theme "Save Sentient Beings" in the "Let's Write" 
activity. In these activities, the book stimulated the students to look for the characteristics of the two ASEAN countries. These characteristics consist of in terms of differences and terms of equality. Then, students are asked to pour thoughts about the characteristics of the two ASEAN countries into the Venn diagram (Anggari et al., 2018). The activity shows learning material that seeks to stimulate students to use effective reasoning and systematic thinking systems. In the first lesson, the sub-theme "I Take Care of My Body", the theme "Myself" in PS / MI Class I also shows the same thing, but in a different context. The book presents the activity "Come On Observing". One of these books presents a case that Udin loves to paint with his fingers. Then, after recess, Udin was hungry and wanted to eat. However, Udin's hands were still full of dirty paint. This case is where the problem arises, namely what Udin should have taken? (Hendrifiana et al., 2017). The "Let's Observe" activity presents information and cases that are part of the material to try to stimulate students to learn to solve problems.

The subject matter for PS / MI also presents material content that fosters communication skills. As an example, in learning four sub-theme "I am Special" the theme "Myself" in the Thematic Book for PS / MI Students Class I presents "Let's Try" activities. In these activities, the book presents material about the diversity of family members' preferences. Then, the next material in the form of the question "Have you ever done activities with your family? What are you doing? Share experiences with friends and teachers "(Hendrifiana et al., 2017). Activities of students to tell their experiences to friends and teachers is one of the efforts to stimulate and train students' communication skills. Thematic Book for PS / MI Class VI Students learning first, the sub-theme "My Friends Plant", the theme "Save Sentient Beings", the activity "Let's Discuss" also presents the same thing. In these activities, the teacher asks students to make observations on flowering plants in the surrounding environment. Then, the teacher asks students to present the observations to their group friends (Anggari et al., 2018). Activities in the form of conveying the findings of observations are one of the activities that can train students' communication skills with their peers.

The subject matter for PS / MI also presents material contents that stimulate and practice collaboration skills. Such content can be found in all sub-themes and in almost every lesson. As an example, in the Thematic Book for Class I Second Learning students, the subtheme "Me and My New Friends", the theme "Myself", the "Let's Tell Story" activities. In the "Let's Tell Stories" activity, learning material invites students to play the "Friends Story" game. The rules of the game are that one participant gives the signal. After that, one participant moved the handkerchief to the other participants around. When the handkerchief stops with one of the participants, he must introduce the friend next to him (Hendrifiana et al., 2017). 
Games in groups with each participant have their respective roles in the game "Friends Story" shows one positive activity that trains students in collaborative skills.

Seventh, the subject matter is integrated with strengthening character education and literacy. According to the "Handbook of Learning Oriented Higher-Order Thinking Skills", Strengthening the Character Education (SCE) and literacy should be the basis for the formulation of the core activities of learning in the education unit (Ariyana et al., 2018, p. 49). The National Literacy Movement Team (GLN) explained that one of the implementations of the literacy movement is using the principle of wholeness and holistic. The point is the development and implementation of a basic literacy implementation holistically. That is to say, literacy, numeracy literacy, scientific literacy, digital literacy, financial literacy, and cultural and citizenship literacy. The development and application of basic literacy need to maintain harmony, harmony, and harmony with the development of character quality) and competence (in the 2013 Curriculum) as the main spirit of 21st century skills (The Drafting Team of the National Literacy Movement, 2017a, p. 7). In line with the explanation of the book "National Literacy Movement Guide" namely, "Literacy can also be integrated in teaching and learning activities in schools so that it becomes an inseparable part of all the series of activities of students and educators, both inside and outside the classroom". (The Drafting Team of the National Literacy Movement, 2017b, p. 19). The explanation emphasizes that the subject matter in SD / MI is required to be able to present career and literacy education materials integrally.

These findings reinforce the opinions of Prastowo, Trianto, and Khaeruddin, and friends, who state that the integrated curriculum is the parent that gives birth to thematicintegrated learning (Khaeruddin \& Junaedi, 2007, p. 204; Prastowo, 2016, p. 59; Trianto, 2013, pp. 147-148). Integrated curriculum changes that make the presentation of subject matter turn into thematic-integrated also reinforce Veken's explanation that curriculum changes can affect teaching changes with various elements (Veken et al., 2009). In other words, the change in the way of presenting the subject matter from the presentation of subject-based teaching materials to the presentation of thematically-integrated teaching materials becomes a necessity if the curriculum approach changes to an integrated curriculum.

\section{Conclusions}

The existence of 2013 Curriculum regulations in Indonesia that replaces the 2006 Curriculum regulations has created curriculum changes in PS / MI. These changes have an impact on some aspects in the subject matter in PS / MI. Changes in subject matter as a result 
of the 2013 Curriculum regulations include seven aspects. Changes to the subject matter in the seven aspects include: first, the presentation of subject matter in an integrated thematic for all subjects, except Physical Education, Sports, and Health (specifically classes IV, V, and VI) and Mathematics subjects (specifically class IV , V, and VI) and Islamic Religious Education in all classes; second, the subject matter is presented contextually with the flow of presentation of material from concrete to abstract; third, teaching material has been prepared and is ready for use, not made by teachers; fourth, the material is prepared with a scientific approach; fifth, the subject matter for all subjects in the realm of knowledge and skills is taught in a direct learning mode, except subjects in Civic Education and Islamic Religious Education; sixth, the subject matter is structured to stimulate critical thinking, creative, communicative, and collaborative skills for students; and seventh, the subject matter is integrated with strengthening character education and literacy. The findings of this study should still be followed up with subsequent studies with different approaches, such as quantitative research approaches with a focus on measuring the quantitative impact of changes in 2013 Curriculum regulations on the proportion of literacy content, higher-order thinking skills, character education, $21^{\text {st }}$ century skills in the subject matter at PS / MI. 


\section{REFERENCES}

Afrizal. (2017). Metode Penelitian Kualitatif: Sebuah Upaya Mendukung Penggunaan Penelitian Kualitatif dalam berbagai Disiplin Illmu (4th ed.). RajaGrafindo Persada.

Anderson, J. E. (2003). Public Policymaking: An Introduction, Fifth Ediition (VI). Houghton Mifflin Company.

Anggari, A. S., Wulan, D. R., Puspitawati, N., Khasanah, L. M., \& Hendriyati, S. (2018). Selamatkan Makhluk Hidup: Tematik Terpadu Kurikulum 2013 untuk SD/MI Kelas VI, Edisi Revisi (2nd ed.). Kementerian Pendidikan dan Kebudayaan Republik Indonesia.

Ariyana, Y., Pudjiastuti, A., Bestary, R., \& Zamroni. (2018). Buku Pegangan Pembelajaran Berorientasi Keterampilan Berpikir Tingkat Tinggi. Direktorat Jenderal Guru dan Tenaga Kependidikan, Kementerian Pendidikan dan Kebudayaan Republik Indonesia.

Fattah, N. (2014). Analisisi Kebijakan Pendidikan (3rd ed.). Remaja Rosdakarya.

Greybeck, B., Gomez, M. O., \& Mendoza, S. O. (2004). The impact of curriculum redesign in a Mexican university on students' abilities, attitudes and values. International Journal of Leadership in Education, 7(3), 243-255. https://doi.org/10.1080/1360312042000213868

Guthrie, G. (1986). Current research in developing countries: The impact of curriculum reform on teaching. Teaching and Teacher Education, 2(1), 81-89. https://doi.org/10.1016/0742-051X(86)90006-5

Handal, B., \& Herrington, A. (2003). Mathematics teachers' beliefs and curriculum reform. Mathematics Education Research Journal, 15(1), 59-69. https://doi.org/10.1007/BF03217369

Hendrifiana, Y., Ariguntar, P., \& Assagaf, L. (2017). Diriku: Tematik Terpadu Kurikulum 2013 Untuk SD/MI Kelas I, Edisi Revisi (4th ed.). Kementerian Pendidikan dan Kebudayaan Republik Indonesia.

Hidayat, S. (2015). Pengembangan Kurikulum Baru. Remaja Rosdakarya.

Inayati, I. N., \& Trianingsih, R. (2019). Relevansi Pendekatan Pembelajaran Tematik Integratif Di SD/MI Dengan Konsep Madrasah/Sekolah Ramah Anak. Tarbiyatuna : Kajian Pendidikan Islam, 3(2), 139-153. https://doi.org/10.29062/tarbiyatuna.v3i2.264 
Indarti, N., \& Paramita, W. (2017). Kajian Literature: Pemetaan Riset Terkini dan Identifikasi Peluang. In Filosofi dan Metodologi Penelitian. BPFE-Yogyakarta.

Irwanto, N., \& Suryana, Y. (2016). Kompetensi Pedagogik Untuk Peningkatan dan Penilaian Kinerja Guru Dalam Rangka Implementasi Kurikulum Nasional. Genta Group Production.

Khaeruddin, \& Junaedi, M. (2007). Kurikulum Tingkat Satuan Pendidikan: Konsep dan Implementasinya di Madrasah. MDC Central Java coperated with Pilar Media.

Leo Agung,. (2015). Sejarah Kurikulum Sekolah menengah di Indonesia (Cet, I). Ombak.

Li, Q., \& Ni, Y. (2011). Impact of curriculum reform: Evidence of change in classroom practice in mainland China. International Journal of Educational Research, 50(2), 71-86. https://doi.org/10.1016/j.ijer.2011.06.003

Minister of Education and Culture. (2013a). Buku Teks Pelajaran dan Buku Panduan Guru untuk Pendidikan Dasar dan Menengah, Peraturan Menteri Pendidikan dan Kebudayaan No. 71 Tahun 2013. Ministry of Education and Culture (MOEC).

Minister of Education and Culture. (2013b). Implementasi Kurikulum, Peraturan Menteri Pendidikan dan Kebudayaan No. 81A Tahun 2013. Ministry of Education and Culture (MOEC).

Minister of Education and Culture. (2013). Kerangka Dasar dan Struktur Kurikulum 2013 Sekolah Dasar / Madrasah Ibtidaiyah, Peraturan Menteri Pendidikan dan Kebudayaah Nomor 67 Tahun 2013. The Ministry of Education and Culture.

Minister of Education and Culture. (2013c). Kerangka Dasar dan Struktur Kurikulum Sekolah Dasar / Madrasah Ibtidaiyah, Peraturan Menteri Pendidikan dan Kebudayaan No. 67 Tahun 2013. Ministry of Education and Culture (MOEC).

Minister of Education and Culture. (2013d). Standar Kompetensi Lulusan Pendidikan Dasar dan Menengah, Peraturan Menteri Pendidikan dan Kebudayaan No. 54 Tahun 2013. Ministry of Education and Culture (MOEC).

Minister of Education and Culture. (2013e). Standar Isi Pendidikan Dasar dan Menengah, Peraturan Menteri Pendidikan dan Kebudayaan No. 64 Tahun 2013. Ministry of Education and Culture (MOEC). 
Minister of Education and Culture. (2013f). Standar Penilaian Pendidikan Dasar dan Menengah, Peraturan Menteri Pendidikan dan Kebudayaan No. 66 Tahun 2013. Ministry of Education and Culture (MOEC).

Minister of Education and Culture. (2013g). Standar Proses Pendidikan Dasar dan Menengah, Peraturan Menteri Pendidikan dan Kebudayaan No. 65 Tahun 2013. Ministry of Education and Culture (MOEC).

Minister of Education and Culture. (2014a). Evaluasi Kurikulum pada Pendidikan Dasar dan Menengah, Peraturan Menteri Pendidikan dan Kebudayaan No. 159/2014. Ministry of Education and Culture (MOEC).

Minister of Education and Culture. (2014b). Kegiatan Ekstrakurikuler pada Pendidikan Dasar dan Menengah, Peraturan Menteri Pendidikan dan Kebudayaan No. 62/2014. Ministry of Education and Culture (MOEC).

Minister of Education and Culture. (2014c). Kurikulum 2013 Sekolah Dasar / Madrasah Ibtidaiyah, Peraturan Menteri Pendidikan dan Kebudayaan No. 57 Tahun 2014. Ministry of Education and Culture (MOEC).

Minister of Education and Culture. (2014d). Kurikulum Tingkat Satuan Pendidikan pada Pendidikan Dasar dan Menengah, Peraturan Menteri Pendidikan dan Kebudayaan No. 61/2014. Ministry of Education and Culture (MOEC).

Minister of Education and Culture. (2014e). Pembelajaran pada Pendidikan Dasar dan Menengah, Peraturan Menteri Pendidikan dan Kebudayaan No. 103 Tahun 2014. Ministry of Education and Culture (MOEC).

Minister of Education and Culture. (2014f). Pendampingan Pelaksanaan Kurikulum 2013 pada Pendidikan Dasar dan Menengah, Peraturan Menteri Pendidikan dan Kebudayaan No. 105/2014. Ministry of Education and Culture (MOEC).

Minister of Education and Culture. (2014g). Pendidikan Kepramukaan sebagai Kegiatan Ekstrakurikuler Wajib pada Menengah, Peraturan Menteri Pendidikan dan Kebudayaan No. 63/2014. Ministry of Education and Culture (MOEC).

Minister of Education and Culture. (2014h). Penilaian Hasil Belajar oleh Pendidik pada Pendidikan Dasar dan Menengah, Peraturan Menteri Pendidikan dan Kebudayaan No. 104 Tahun 2014. Ministry of Education and Culture (MOEC).

Minister of Education and Culture. (2015). Penilaian Hasil Belajar oleh Pendidik dan Satuan 
Pendidikan pada Pendidikan Dasar dan Menengah, Peraturan Menteri Pendidikan dan Kebudayaan No. 53 Tahun 2015. The Ministry of Education and Culture.

Minister of Education and Culture. (2016a). Buku yang Digunakan oleh Satuan Pendidikan, Peraturan Menteri Pendidikan dan Kebudayaan No. 8 Tahun 2016. The Ministry of Education and Culture.

Minister of Education and Culture. (2016b). Kompetensi Inti dan Kompetensi Dasar Pelajaran pada Kurikulum 2013, Peraturan Menteri Pendidikan Dasar dan Menengah No. 24 Tahun 2016. The Ministry of Education and Culture.

Minister of Education and Culture. (2016c). Standar Isi Pendidikan Dasar dan Menengah, Peraturan Menteri Pendidikan Dasar dan Menengah No. 21 Tahun 2016. The Ministry of Education and Culture.

Minister of Education and Culture. (2016d). Standar Kompetensi Lulusan Pendidikan Dasar dan Menengah, Peraturan Menteri Pendidikan dan Kebudayaan No. 20 Tahun 2016. The Ministry of Education and Culture.

Minister of Education and Culture. (2016e). Standar Penilaian Pendidikan Dasar dan Menengah, Peraturan Menteri Pendidikan Dasar dan Menengah No. 23 Tahun 2016. The Ministry of Education and Culture.

Minister of Education and Culture. (2016f). Standar Proses Pendidikan Dasar dan Menengah, Peraturan Menteri Pendidikan Dasar dan Menengah No. 22 Tahun 2016. The Ministry of Education and Culture.

Minister of Education and Culture. (2018). Perubahan Atas Peraturan Menteri Pendidikan dan Kebudayaan No. 24 tahun 2016 tentang Kompetensi Inti dan Kompetensi Dasar Pelajaran Kurikulum 2013, Peraturan Menteri Pendidikan dan Kebudayaan Republik Indonesia Nomor 37 Tahun 2018. The Ministry of Education and Culture.

Minister of Religious Affairs. (2014a). Implementasi Kurikulum 2013 di Madrasah, Keputusan Menteri Agama No. 117 Tahun 2014. The Ministry of Religious Affairs.

Minister of Religious Affairs. (2014b). Kurikulum Madrasah, Keputusan Menteri Agama No. 207 Tahun 2014. The Ministry of Religious Affairs.

Minister of Religious Affairs. (2014c). Pedoman Kurikulum Madrasah 2013 Mata Pelajaran Pendidikan Agama Islam dan Bahasa Arab, Keputusan Menteri Agama No. 165 Tahun 2014. The Ministry of Religious Affairs. 
Minister of Religious Affairs. (2019a). Kurikulum Pedidikan Agama Islam dan Bahasa Arab pada Madrasah, Keputusan Menteri Agama Nomor 183/2019. The Ministry of Religious Affairs.

Minister of Religious Affairs. (2019b). Pedoman Implementasi Kurikulum di Madrasah, Keputusan Menteri Agama Nomor 184/2019. The Ministry of Religious Affairs.

Moyer, J. C., Cai, J., Wang, N., \& Nie, B. (2011). Impact of curriculum reform: Evidence of change in classroom practice in the United States. International Journal of Educational Research, 50(2), 87-99. https://doi.org/10.1016/j.ijer.2011.06.004

Mulyasa E,. (2013). Pengembangan dan Implementasi Kurikulum 2013 (Cet, I). PT. Rosdakarya.

OECD. (2018). PISA 2018 Results. OECD. https://www.oecd.org/pisa/PISAresults_ENGLISH.png

Prastowo, A. (2014). Pengembangan Bahan Ajar Tematik: Tinjauan Teooritis dan Praktik. Kencana Prenada Media Group.

Prastowo, A. (2016). Pengembangan Bahan Ajar Tematik: Tinjauan Teoritis dan Praktik, Edisi Kedua (2nd ed.). Kencana Prenada Media Group.

President of the Republic of Indonesia. (2003). Sistem Pendidikan Nasional, Undang-Undang Republik Indonesia Nomor 20 Tahun 2003. The Government of the Republic of Indonesia.

President of the Republic of Indonesia. (2005). Standar Nasional Pendidikan, Peraturan Pemerintah No. 19 Tahun 2005. The Government of the Republic of Indonesia.

President of the Republic of Indonesia. (2013). Perubahan atas Peraturan Pemerintah No. 19 Tahun 2015 tentang Standar Nasional Pendidikan, Peraturan Pemerintah No. 32 Tahun 2013. The Government of the Republic of Indonesia.

President of the Republic of Indonesia. (2015). Perubahan Kedua atas Peraturan Peraturan Pemerintah No. 19 Tahun 2005 tentang Standar Nasional Pendidikan, Peraturan Pemerintah No. 13 Tahun 2015. The Government of the Republic of Indonesia.

Shaleh, A. R. (2004). Madrasah dan Pendidikan Anak Bangsa: Visi, Misi dan Aksi. Raja Grafindo Persada. 
Slameto, S. (2015). Rasional dan Elemen Perubahan Kurikulum 2013. Scholaria: Jurnal Pendidikan Dan Kebudayaan, 5(1), 1-9. https://doi.org/10.24246/j.scholaria.2015.v5.i1.p1-9

The Drafting Team of the National Literacy Movement. (2017a). Materi Pendukung Literasi Baca Tulis. The Ministry of Education and Culture.

The Drafting Team of the National Literacy Movement. (2017b). Panduan Gerakan Literasi Nasional. The Ministry of Education and Culture.

Trianto. (2013). Desain Pengembangan Pembelajaran Tematik bagi Anak Usia Dini TK/RA dan Anak Usia Awal SD/MI (2nd ed.). Kencana Prenada Media Group.

Veken, J. V. der, Valcke, M., Maeseneer, J. D., \& Derese, A. (2009). Impact of the transition from a conventional to an integrated contextual medical curriculum on students' learning patterns: A longitudinal study. Medical Teacher, 31(5), 433-441. https://doi.org/10.1080/01421590802141159

Walker, R., Spronken-Smith, R., Bond, C., McDonald, F., Reynolds, J., \& McMartin, A. (2010). The impact of curriculum change on health sciences first year students' approaches to learning. Instructional Science, 38(6), 707-722. https://doi.org/10.1007/s11251-0099092-y 